\title{
Proposal of Mycetocola gen. nov. in the family Microbacteriaceae and three new species, Mycetocola saprophilus sp. nov., Mycetocola tolaasinivorans sp. nov. and Mycetocola lacteus sp. nov., isolated from cultivated mushroom, Pleurotus ostreatus
}

\footnotetext{
${ }^{1}$ National Institute of Sericultural and Entomological Sciences, Ohwashi 1-2, Tsukuba 305-8634, Japan

2 Institute for Fermentation, Osaka, 17-85, Jusohonmachi 2-chome, Yodogawa-ku, Osaka 532-8686, Japan

3 R\&D Department, Higeta Shoyu Co. Ltd, Choshi, Chiba 288-8680, Japan

4 Forestry and Forest Products Research Institute, PO Box 16, Tsukuba-Norin, 305-8687, Japan
}

\author{
Takanori Tsukamoto, ${ }^{1} \uparrow$ Mariko Takeuchi, ${ }^{2}$ Osamu Shida, ${ }^{3}$ Hitoshi Murata ${ }^{4}$ \\ and Akira Shirata ${ }^{1}$
}

Author for correspondence: Takanori Tsukamoto. Tel: +81 45 211 7153. Fax: +81452110611. e-mail: taktak@air.linkclub.or.jp
Keywords: Mycetocola gen. nov., Mycetocola saprophilus sp. nov., Mycetocola tolaasinivorans sp. nov., Mycetocola lacteus sp. nov.

\section{INTRODUCTION}

Pseudomonas tolaasii Paine produces pathogenic extracellular toxins, tolaasins (Nutkins et al., 1991; Shirata et al., 1995), and causes brown blotch disease in economically important cultivated mushrooms Pleurotus ostreatus Kummer and Agaricus bisporus

\footnotetext{
† Present address: Yokohama Plant Protection Station, Kitanakadori 5-57, Naka-ku, Yokohama 231-0003, Japan.

Abbreviation: MAFF, Ministry of Agriculture, Forestry and Fisheries Genebank, National Institute of Agrobiological Resources, Kannondai 2-1-2, Tsukuba, Ibaraki, 305-8602 Japan.

The DDBJ accession numbers for the 16S rRNA gene sequences of strains $\mathrm{CM}-01^{\top}, \mathrm{CM}-05^{\top}$ and $\mathrm{CM}-10^{\top}$ are $\mathrm{AB} 012647, \mathrm{AB} 012646$ and $\mathrm{AB} 012648$, respectively.
}

Singer (Suyama \& Fujii, 1993; Tolaas, 1915). In the course of the microbiological study of brown blotch disease, we isolated from Pleurotus ostreatus fruiting bodies some Gram-positive bacteria which detoxify the tolaasins and suppress the development of the disease (Tsukamoto et al., 1998). They were obligately aerobic, non-sporulating and irregular rod-shaped bacteria. The result of phylogenetic analysis of the $16 \mathrm{~S}$ rRNA gene showed that the tolaasins-detoxifying bacteria belong to the family Microbacteriaceae and bacteriological analyses also supported this result.

The family Microbacteriaceae (Stackebrandt et al., 1997) contains 10 genera: Agrococcus (Groth et al., 1996), Agromyces (Gledhill \& Casida, 1979), Clavibacter (Davis et al., 1984), Cryobacterium (Suzuki et al., 1997), Curtobacterium (Yamada \& Komagata, 
1972), Frigoribacterium (Kämpfer et al., 2000), Leifsonia (Evtushenko et al., 2000), Leucobacter (Takeuchi et al., 1996), Microbacterium (Takeuchi \& Hatano, 1998) and Rathayibacter (Zgurskaya et al., 1993). The bacteria we isolated from Pleurotus ostreatus contain lysine as the diamino acid and acetyltype muramic acid in the peptidoglycan, MK-10 as the major menaquinone, a DNA $\mathrm{G}+\mathrm{C}$ content of $63.9-65 \cdot 2 \mathrm{~mol} \%$ and the isolated bacteria cannot grow at $4{ }^{\circ} \mathrm{C}$. Species of the genus Frigoribacterium and some species of Microbacterium have lysine in the cell wall. However, the isolated bacteria are different from these organisms in that they possess a different menaquinone and have a different $\mathrm{G}+\mathrm{C}$ content and growth temperature. Also, the results of phylogenetic analysis of the 16S rRNA gene revealed that the isolated bacteria form an independent cluster and that this cluster is isolated from any of the subclusters corresponding to the established genera within the family Microbacteriaceae.

This paper describes the unique characteristics of the strains isolated from rotting Pleurotus ostreatus fruiting bodies. The phylogenetic data show that they represent a new genus in the family Microbacteriaceae. Chemotaxonomic and physiological data support this conclusion. We propose a new genus, Mycetocola gen. nov., and three new species, Mycetocola saprophilus sp. nov., Mycetocola tolaasinivorans sp. nov. and Mycetocola lacteus sp. nov.

\section{METHODS}

Bacterial strains. Micro-organisms isolated from rotting Pleurotus ostreatus fruiting bodies were cultured on PS agar medium containing $0.5 \mathrm{~g} \quad \mathrm{Ca}\left(\mathrm{NO}_{3}\right)_{2} .4 \mathrm{H}_{2} \mathrm{O}, 2 \mathrm{~g}$ $\mathrm{Na}_{2} \mathrm{HPO}_{4} \cdot 12 \mathrm{H}_{2} \mathrm{O}, 5 \mathrm{~g}$ peptone, $15 \mathrm{~g}$ sucrose and $15 \mathrm{~g}$ agar in 11 of a decoction of $300 \mathrm{~g}$ potato tuber slices $(\mathrm{pH} 7 \cdot 0)$ as described by Wakimoto (1955). Ten strains were selected as tolaasins-detoxifying strains by using the potato tuber slice method (Shirata et al., 1995) (Table 1). All strains were cultured aerobically at $28^{\circ} \mathrm{C}$ in a peptone/yeast extract medium (PY medium) containing $10 \mathrm{~g}$ peptone, $2 \mathrm{~g}$ yeast extract, $2 \mathrm{~g} \mathrm{NaCl}$ and $2 \mathrm{~g} \mathrm{D}$-glucose in $11 \mathrm{H}_{2} \mathrm{O}(\mathrm{pH} \mathrm{7 \cdot 2)}$. Cells used for biochemical tests were harvested by centrifugation during the stationary phase, washed with water and lyophilized.
Morphological, physiological and biochemical characteristics. Cell morphology was determined by phase-contrast microscopy following growth on PS agar. One-day-old cells in PS broth medium were negatively stained with $2.0 \%$ phosphotungstic acid ( $\mathrm{pH} \mathrm{6.5)}$ and were observed with a JEM-1010 transmission electron microscope(JEOL). Physiological and biochemical characteristics were examined as described by Nishiyama (1981) and Azegami et al. (1987). Dye's medium C (Dye, 1962) and OY medium (Dye, 1968) were used as the basal media for acid production and utilization tests, respectively.

Chemical analyses. Cell walls were prepared from about $500 \mathrm{mg}$ (dry wt) bacterial cells as described by Schleifer \& Kandler (1972). Amino acids in the acid hydrolysate of the cell walls were identified by two-dimensional ascending chromatography on cellulose TLC plates (Tokyo Kasei) by the method of Harper \& Davis (1979) and by HPLC as their phenylthiocarbamoyl derivatives with a model Shimadzu LC-6AD HPLC apparatus, according to the manufacturer's instructions. Glycolate tests were performed by the method of Uchida et al. (1999). Cellular fatty acids were extracted from dried cells $(50 \mathrm{mg})$ by acid methanolysis, purified (Minnikin et al., 1979) and analysed by GLC-MS with a GCMS-QP5000 spectrometer (Shimadzu) combined with a CLASS-5000 MS Workstation computer system. GLC analyses were carried out using a GC-17A gas chromatograph (Shimadzu). A BPX70 capillary column (SGE) containing $70 \%$ cyanopropyl equivalent modified siloxane $(50 \mathrm{~m} \times 0.25 \mathrm{~mm})$ was used at $80{ }^{\circ} \mathrm{C}$ for $2 \mathrm{~min}, 80-150{ }^{\circ} \mathrm{C}$ at $15^{\circ} \mathrm{C} \mathrm{min}{ }^{-1}, 150-250{ }^{\circ} \mathrm{C}$ at $8^{\circ} \mathrm{C} \mathrm{min}^{-1}$ and then $250{ }^{\circ} \mathrm{C}$ for $5 \mathrm{~min}$, with helium as carrier gas at a flow rate of $1.4 \mathrm{ml} \mathrm{min}{ }^{-1}$. Menaquinones were extracted from dry cells (200 mg) with chloroform/methanol (2:1, v/v), purified by silica gel TLC (Kieselgel $60 \mathrm{~F}_{254}$ plates; Merck) using hexane/diethyl ether $(85: 15, \mathrm{v} / \mathrm{v})$ as solvent, extracted with acetone, dried under nitrogen stream and then analysed by HPLC with a Shimadzu model LC-5A instrument equipped with a Zorbax octyldecyl silane column $(150 \times 4.6 \mathrm{~mm})$.

DNA base composition and DNA relatedness. Isolation and purification of chromosomal DNA and estimation of $\mathrm{G}+\mathrm{C}$ content were performed by the methods of Takagi et al. (1993). DNA relatedness values were determined as described by Ezaki et al. (1989).

Amplification and sequencing of the 16S rRNA gene. The $16 \mathrm{~S}$ rRNA gene was amplified by PCR using prokaryotic $16 \mathrm{~S}$ rRNA gene universal primers $27 \mathrm{f}$ (5'-AGAGTTTGATCMTGGCTCAG-3'; position 8-27 in Escherichia coli) and 1492r (5'-TACGGYTACCTTGTTACGACTT-3'; 1513-

Table 1. Bacterial strains isolated from cultivated mushrooms and $16 \mathrm{~S}$ rRNA gene accession numbers

\begin{tabular}{|llll|}
\hline Strain & Geographical origin of mushrooms & Proposed name & DDBJ accession no. \\
\hline CM-01 & & Mycetocola saprophilus & AB012647 \\
CM-02 & Yamagata prefecture, Japan & Mycetocola saprophilus & Mycetocola saprophilus \\
CM-03 & Yamagata prefecture, Japan & Mycetocola tolaasinivorans & AB012646 \\
CM-05 & Yamagata prefecture, Japan & Mycetocola lacteus & AB012648 \\
CM-10 & Ibaraki prefecture, Japan & Mycetocola lacteus & Mycetocola lacteus \\
CM-14 & Gifu prefecture, Japan & Mycetocola lacteus & Mycetocola lacteus \\
CM-15 & Ibaraki prefecture, Japan & Mycetocola lacteus & \\
CM-20 & Ibaraki prefecture, Japan & Ibaraki prefecture, Japan & \\
CM-21 & Ibaraki prefecture, Japan & Ibaraki prefecture, Japan & \\
\hline
\end{tabular}


1492). The PCR products were purified by using a Sepharose $\mathrm{Cl}-2 \mathrm{~B}$ gel (Pharmacia). The sequencing reactions were performed by using an ABI PRISM BigDye Terminator Cycle Sequencing Ready Reaction Kit (Applied Biosystems). Primers used for sequencing were 27f, 530f (5'GTGCCAGCMGCCGCGG-3'; 515-530), 1114f (5'-GCAACGAGCGCAACCC-3'; 1099-1114), 515r (5'-CCGCGGCKGCTGGCAC-3'; 530-515), 1100r (5'-GGGTTGCGCTCGTTG-3'; 1114-1100) and 1492r. All PCR reactions were performed with a Perkin-Elmer Cetus model 9600 thermal cycler. Each extension product resulting from the sequencing reaction was purified through a Centri-Sep spin column (Applied Biosystems) and sequenced by using an ABI model 377 automated DNA sequencer.

Phylogenetic analysis and nucleotide sequence accession numbers. The multiple alignment of sequences, calculation of nucleotide substitution rates ( $K_{\text {nue }}$ values; Kimura, 1980), construction of a neighbour-joining phylogenetic tree (Saitou \& Nei, 1987) and a bootstrap analysis with 1000 replicates for evaluation of phylogenetic tree topology (Felsenstein, 1985) were carried out with the CLUSTAL W multiple sequence alignment program (Thompson et al., 1994). The $16 \mathrm{~S}$ rRNA gene sequences determined in this study have been deposited in the DDBJ database under the accession numbers shown in Table 1.

\section{RESULTS}

\section{Morphological, biochemical and physiological characteristics}

All of the strains were Gram-positive, non-sporulating, non-motile, irregular rods, $0 \cdot 2-0 \cdot 4 \mu \mathrm{m}$ wide and $2 \cdot 0-$ $3.5 \mu \mathrm{m}$ long in PS broth medium (Fig. 1). They were

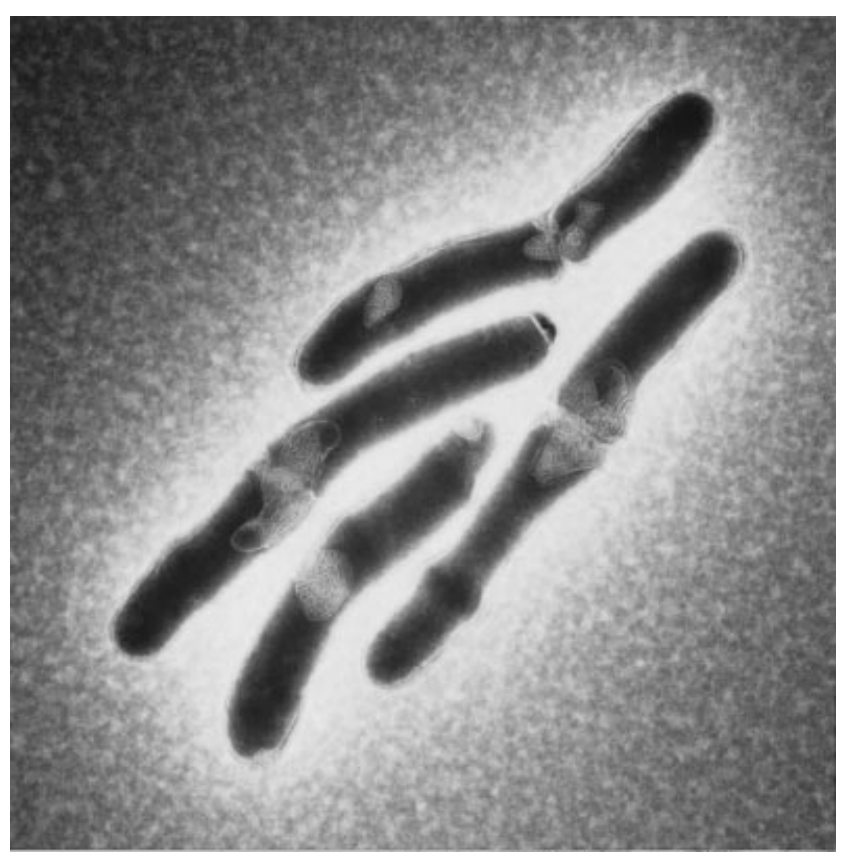

Fig. 1. Electron micrograph of negatively stained cells of Mycetocola saprophilus, showing pleomorphic, rod-shaped cells with mesosomes. Cells are 0.2-0.4 $\mu \mathrm{m}$ wide and 2.0-3.5 $\mu \mathrm{m}$ long. aerobic and no growth was found under anaerobic conditions. The strains formed smooth, yellowishwhite colonies on PS agar. The optimal temperature for growth was $25^{\circ} \mathrm{C}$ and the maximum temperature for growth was $33^{\circ} \mathrm{C}$ for all strains. No strain grew at $4{ }^{\circ} \mathrm{C}$. Ten strains were divided into three groups. The first group contains three strains, CM- $01^{\mathrm{T}}, \mathrm{CM}-02$ and CM-03, which did not hydrolyse Tween 80 and did not produce acid from erythritol, but did produce acid from melezitose and utilize citrate. The second group contains one strain, $\mathrm{CM}-05^{\mathrm{T}}$, which did not hydrolyse Tween 80, did not produce acid from erythritol and melezitose and did not utilize citrate. The third group is composed of six strains, CM-10 ${ }^{\mathrm{T}}$, CM-14, CM-15, CM-16, CM-20 and CM-21, which hydrolysed Tween 80 , produced acid from erythritol and melezitose and utilized citrate.

\section{Chemotaxonomic characteristics}

The amino acid composition of the cell walls of the representative strains of each group was glutamic acid, glycine, alanine, lysine and an unknown amino acid in the molar ratio of $0 \cdot 60: 1 \cdot 50: 1 \cdot 00: 2 \cdot 14: 1 \cdot 03$ for strain CM-01 ${ }^{\mathrm{T}}, 2 \cdot 11: 2 \cdot 06: 1 \cdot 00: 1 \cdot 74: 0 \cdot 94$ for strain $\mathrm{CM}-05^{\mathrm{T}}$ and $1 \cdot 69: 1 \cdot 39: 1 \cdot 00: 1 \cdot 11: 0 \cdot 80$ for strain CM-10 ${ }^{\mathrm{T}}$. Despite further analysis using two-dimensional paper chromatography, the identification of the unknown amino acid was unsuccessful. The glycan moiety of the cell walls of all strains contained acetyl residues. Cellular fatty acids of all the strains were composed mainly of anteiso- $\mathrm{C}_{15: 0}$, anteiso- $\mathrm{C}_{17: 0}$ and iso- $\mathrm{C}_{16: 0}$, and the composition ratios were approximately 56,39 and $5 \%$ in strains $\mathrm{CM}-01^{\mathrm{T}}, \mathrm{CM}-02$ and $\mathrm{CM}-03,63,33$ and $4 \%$ in strain $\mathrm{CM}-05^{\mathrm{T}}$ and 51,46 and $3 \%$ in strains $\mathrm{CM}-10^{\mathrm{T}}, \mathrm{CM}-14, \mathrm{CM}-15, \mathrm{CM}-16, \mathrm{CM}-20$ and CM-21, respectively. These classifications agree with the results derived from the biochemical and physiological tests (see above). The menaquinones of strain $\mathrm{CM}-01^{\mathrm{T}}$ were MK-10 (53\%), MK-9 (23\%), MK-11 (12\%) and MK$8(8 \%)$, those of strain CM- $05^{\mathrm{T}}$ were MK-10 $(58 \%)$, MK-9 (21\%), MK-11 (14\%) and MK-8 (4\%), and those of strain CM-10 ${ }^{\mathrm{T}}$ were MK-10 (54\%), MK-9 $(21 \%)$, MK-11 (14\%) and MK-8 (4\%).

\section{DNA relatedness}

The levels of DNA relatedness were analysed and the results are presented in Table 2 . Three strains $\mathrm{CM}-01^{\mathrm{T}}$, CM-02 and CM-03 were related with $81-96 \%$ homology and the levels among the other seven strains ranged from 12 to $54 \%$. Strain $\mathrm{CM}-05^{\mathrm{T}}$ did not show a high level of DNA relatedness with any other strains $(18-28 \%)$. Six strains, CM-10 ${ }^{\mathrm{T}}, \mathrm{CM}-14, \mathrm{CM}-15$, CM16, CM-20 and CM-21, showed a high level of DNA relatedness with each other (79-84\%), but did not show a high level of relatedness with the other four strains $(16-52 \%)$. On the basis of these results, the three groups into which the 10 strains have been divided can be classified at the species level. 
Table 2. DNA base composition and DNA relatedness of the strains

\begin{tabular}{|c|c|c|c|c|}
\hline \multirow[t]{2}{*}{ Strain } & \multirow{2}{*}{$\begin{array}{c}\mathbf{G}+\mathbf{C} \text { content } \\
(\mathbf{m o l} \%)\end{array}$} & \multicolumn{3}{|c|}{ DNA relatedness (\%) with: } \\
\hline & & $\mathrm{CM}^{\mathrm{C} 01^{\mathrm{T}}}$ & CM-05 ${ }^{\mathrm{T}}$ & CM-10 ${ }^{\mathrm{T}}$ \\
\hline $\mathrm{CM}-01^{\mathrm{T}}$ & $65 \cdot 2$ & 100 & 26 & 45 \\
\hline CM-02 & $65 \cdot 2$ & 81 & 23 & 42 \\
\hline CM-03 & $65 \cdot 2$ & 96 & 26 & 52 \\
\hline $\mathrm{CM}-05^{\mathrm{T}}$ & $65 \cdot 1$ & 12 & 100 & 16 \\
\hline $\mathrm{CM}-10^{\mathrm{T}}$ & $63 \cdot 9$ & 42 & 18 & 100 \\
\hline CM-14 & $64 \cdot 6$ & 46 & 28 & 79 \\
\hline CM-15 & $64 \cdot 6$ & 46 & 25 & 84 \\
\hline CM-16 & $64 \cdot 6$ & 46 & 23 & 80 \\
\hline CM-20 & $64 \cdot 6$ & 54 & 25 & 84 \\
\hline CM-21 & $64 \cdot 7$ & 47 & 26 & 79 \\
\hline
\end{tabular}

\section{Phylogenetic analysis of 16S rRNA gene}

Almost complete 16S rRNA gene sequences of 1444 or 1445 bases of the 10 strains were determined. Strains CM-01 ${ }^{\mathrm{T}}, \mathrm{CM}-02$ and CM-03 had identical 16S rRNA gene sequences as did strains CM-10 ${ }^{\mathrm{T}}, \mathrm{CM}-14, \mathrm{CM}-15$,
CM-16, CM-20 and CM-21. The phylogenetic tree based on calculated $K_{\text {nuc }}$ values clearly shows that the representative strains $\mathrm{CM}-01^{\mathrm{T}}, \mathrm{CM}-05^{\mathrm{T}}$ and $\mathrm{CM}-10^{\mathrm{T}}$ formed an independent cluster at the base of the Microbacterium cluster in the family Microbacteriaceae with a $100 \%$ bootstrap confidence level (Fig. 2).

\section{DISCUSSION}

We isolated from rotting Pleurotus ostreatus fruiting bodies 10 micro-organisms that markedly reduce the level of extracellular toxins, tolaasins, produced by Pseudomonas tolaasii, the most destructive pathogen of cultivated mushrooms. They were saprophytic, but not parasitic nor pathogenic to Pleurotus ostreatus (Tsukamoto et al., 1998). To clarify the taxonomic positions of these bacteria, we examined their morphological, physiological and chemotaxonomic characteristics, together with DNA-DNA reassociation values and 16S rRNA gene sequence comparisons. The strains are Gram-positive, obligately aerobic, non-sporulating and irregular rod-shaped bacteria with high $\mathrm{G}+\mathrm{C}$ contents $(64-65 \mathrm{~mol} \%)$ and they also have the following characteristics: the

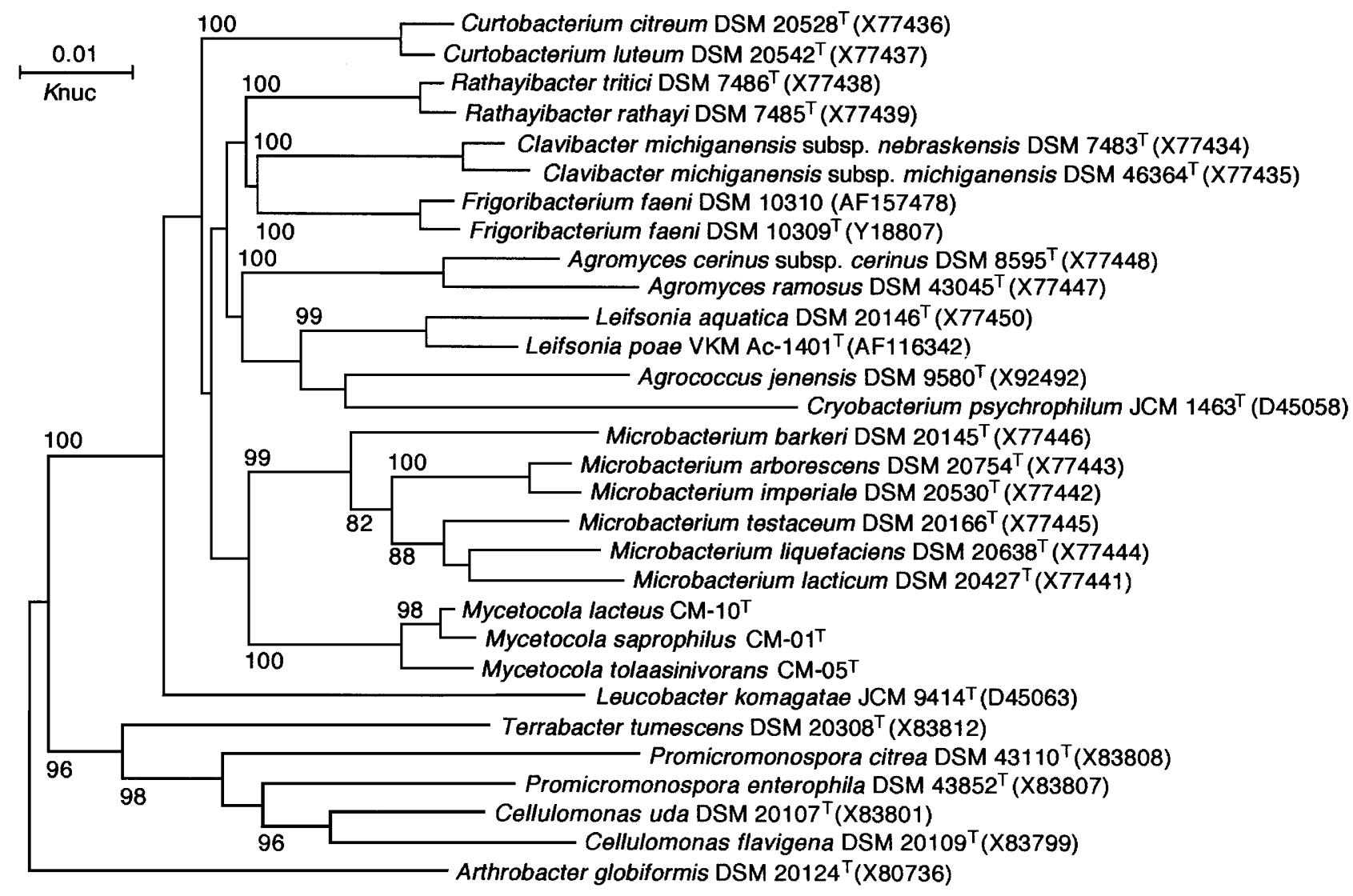

Fig. 2. Phylogenetic tree based on $16 \mathrm{~S}$ rRNA gene sequences of Mycetocola species and some close relatives. The tree was created by the neighbour-joining method and the numerals indicate the percentages of bootstrap samplings, derived from 1000 replications. 
Table 3. Distinguishing characteristics between Mycetocola gen. nov. and other genera in the family Microbacteriaceae

Data from Evtushenko et al. (2000), Kämpfer et al. (2000) and Takeuchi \& Hatano (1998). DAB, 2,4-diaminobutyric acid; Lys, lysine; Orn, ornithine; ND, not determined.

\begin{tabular}{|c|c|c|c|c|}
\hline \multirow[t]{2}{*}{ Genus } & \multicolumn{2}{|c|}{ Peptidoglycan } & \multirow{2}{*}{$\begin{array}{c}\text { Major } \\
\text { menaquinone }\end{array}$} & \multirow[t]{2}{*}{$\mathrm{G}+\mathrm{C}$ content $(\mathrm{mol} \%)$} \\
\hline & Diamino acid & Acyl type & & \\
\hline Mycetocola & Lys & Acetyl & MK-10 & $64-65$ \\
\hline Agrococcus & L-DAB & Acetyl & MK-11, 12 & 74 \\
\hline Agromyces & L-DAB & Acetyl & MK-11, 12 & $71-76$ \\
\hline Clavibacter & DL-DAB & Acetyl & MK-9, 10 & $67-78$ \\
\hline Cryobacterium & L-DAB & ND & MK-10 & 65 \\
\hline Curtobacterium & Orn & Acetyl & MK-9 & $68-75$ \\
\hline Frigoribacterium & Lys & Acetyl & MK-9 & $71 \cdot 7$ \\
\hline Leifsonia & DL-DAB & $\mathrm{ND}$ & MK-10, 11 & $66-73$ \\
\hline Leucobacter & L-DAB & Acetyl & MK-11 & $66 \cdot 2$ \\
\hline Microbacterium & Lys/Orn & Glycolyl & MK-11, 12, 13, 14 & $65-72$ \\
\hline Rathayibacter & L-DAB & ND & MK-10 & $63-72$ \\
\hline
\end{tabular}

major menaquinone is MK-10, the diamino acid in the cell wall is lysine and the muramic acid in the peptidoglycan is an acetyl type.

The result of phylogenetic analysis of the 16S rRNA gene sequences revealed that these strains form a monophyletic and distinct cluster, and that this cluster was isolated from any of the subclusters corresponding to the established genera within the family Microbacteriaceae. On the basis of the data described above, we concluded that these strains should belong to a new genus in the family Microbacteriaceae. Therefore, we propose a new genus, Mycetocola gen. nov., for these bacteria isolated from mushrooms. This conclusion was supported by the results of chemotaxonomic studies. Table 3 shows some of the characteristics that distinguish the new genus and other genera of Microbacteriaceae. In the family Microbacteriaceae, the genus Frigoribacterium is the only genus that has lysine as a diamino acid and acetyl-type muramic acid in the peptidoglycan. However, the genus Mycetocola can be distinguished from the genus Frigoribacterium by motility, growth temperature, major menaquinone content, major fatty acid content and DNA G $+C$ content. Frigoribacterium is motile, grows at $2{ }^{\circ} \mathrm{C}$ (optimal temperature for growth is $4-10^{\circ} \mathrm{C}$ ), the major menaquinone is $\mathrm{MK}-9$, the major fatty acids are anteiso- $\mathrm{C}_{15: 0}$ and iso- $\mathrm{C}_{16: 0}$, and the $\mathrm{G}+\mathrm{C}$ content is $71.7 \mathrm{~mol} \%$. Mycetocola is non-motile, does not grow at $4{ }^{\circ} \mathrm{C}$, the major menaquinone is $\mathrm{MK}-10$, the major fatty acids are anteiso- $\mathrm{C}_{15: 0}$ and anteiso- $\mathrm{C}_{17: 0}$, and the $\mathrm{G}+\mathrm{C}$ content is $63 \cdot 9-65 \cdot 2 \mathrm{~mol} \%$.

The 10 strains in the genus Mycetocola can be divided into three species according to the results of DNADNA hybridization tests (Table 2). This conclusion was supported by the results of phenotypic characterization, hydrolysis of Tween 80 , acid production from erythritol or melezitose, utilization of citrate and patterns of cellular fatty acids. 16S rRNA gene sequence analysis of the representative strains of these three groups reinforced their status as novel species in the genus Mycetocola. On the basis of these physiological and chemotaxonomic characteristics, and the result of phylogenetic analysis together with DNADNA reassociation, we propose the new species Mycetocola saprophilus sp. nov., Mycetocola tolaasinivorans sp. nov. and Mycetocola lacteus sp. nov. The type species of the genus is Mycetocola saprophilus.

\section{Description of Mycetocola gen. nov.}

Mycetocola (my.ce'to.co.la. L. n. myceto fungus; Gr. adj. -cola inhabitant; M.L. masc. n. mycetocola fungus-dweller).

Cells are Gram-positive, obligately aerobic, irregular rods, $0.2-0.4 \times 2.0-3.5 \mu \mathrm{m}$. Endospores are not produced. Non-motile. Colonies are circular, convex, smooth and yellowish-white on PS agar. Growth optimal at $25^{\circ} \mathrm{C}$, but no growth above $33{ }^{\circ} \mathrm{C}$ nor at $4{ }^{\circ} \mathrm{C}$ in PS broth medium. Catalase is produced, but oxidase is not produced. The following tests are positive: aesculin hydrolysis, growth in peptone water, acid production from D-cellobiose, dextrin, D-fructose, D-galactose, D-glucose, glycerol, lactose, maltose, Dmannitol, D-mannose, melibiose, D-ribose, salicin, D-sorbitol, sucrose, trehalose and D-xylose, and utilization of fumarate. The following tests are negative: reduction of nitrate or nitrite, nitrate respiration, liquefaction of gelatin, Voges-Proskauer reaction, methyl red reaction, lecithinase, tyrosinase, urease, hydrolysis of arbutin, arginine and casein, production of diffusible and fluorescent pigment, hydrogen sulfide, indole, 3-ketolactose, 2-ketogluconate and levan from sucrose, growth in Corn's solution, Fermi's solution and Uschinsky's solution, utilization of asparagine as sole source of carbon and nitrogen, maceration of potato tubers, hypersensitive reaction in tobacco leaves, acid production from $\mathrm{D}$-arabinose, $\mathrm{L}$-arabinose, 
D-dulcitol, $m$-inositol, inulin, D-raffinose, L-rhamnose and starch, and utilization of benzoate, butyrate, $m$ hydroxybenzoate, malonate, oxalate, propionate, Dand L-tartarate. All strains of the genus have the ability to detoxify tolaasins produced by Pseudomonas tolaasii. Cell wall peptidoglycan contains lysine as a diamino acid and the muramic acid of the cell wall is an acetyl type. The major isoprenoid quinone is menaquinone MK-10 and small amounts of MK-9 and MK-11 are present. The major fatty acids are anteiso$\mathrm{C}_{15: 0}$ and anteiso- $\mathrm{C}_{17: 0}$. The $\mathrm{G}+\mathrm{C}$ content is 63.9$65 \cdot 2 \mathrm{~mol} \%$. Forms an independent phylogenetic cluster at the base of the Microbacterium cluster in the family Microbacteriaceae. Type species is Mycetocola saprophilus. Isolated from cultivated mushroom Pleurotus ostreatus.

\section{Description of Mycetocola saprophilus sp. nov.}

Mycetocola saprophilus (sa.pro.ph'il.us. Gr. adj. sapros putrid; Gr. adj. philus loving; M.L. adj. saprophilus putrid-loving).

Cells are Gram-positive, obligately aerobic, irregular rods, $0 \cdot 2-0.4 \times 2.0-3.5 \mu \mathrm{m}$, non-sporulating and nonmotile. Smooth, yellowish-white colonies are found on PS agar. The maximum temperature for growth is $33^{\circ} \mathrm{C}$ and the optimal temperature for growth is $25^{\circ} \mathrm{C}$, but no growth at $4^{\circ} \mathrm{C}$ in PS broth medium. Catalase is produced, but oxidase is not produced. The following tests are positive: aesculin hydrolysis, growth in peptone water, acid production from D-cellobiose, dextrin, D-fructose, D-galactose, D-glucose, glycerol, lactose, maltose, D-mannitol, D-mannose, melezitose, melibiose, D-ribose, salicin, D-sorbitol, sucrose, trehalose and D-xylose, utilization of citrate and fumarate, and detoxification of tolaasins produced by Pseudomonas tolaasii. The following tests are negative: reduction of nitrate or nitrite, nitrate respiration, liquefaction of gelatin, Voges-Proskauer reaction, methyl red reaction, lecithinase, tyrosinase, urease, hydrolysis of arbutin, arginine, casein and Tween 80, production of diffusible and fluorescent pigment, hydrogen sulfide, indole, 3-ketolactose, 2-ketogluconate and levan from sucrose, growth in Corn's solution, Fermi's solution and Uschinsky's solution, utilization of asparagine as sole source of carbon and nitrogen, maceration of potato tubers, hypersensitive reaction in tobacco leaves, acid production from D-arabinose, L-arabinose, D-dulcitol, erythritol, $m$-inositol, inulin, D-raffinose, L-rhamnose and starch, and utilization of benzoate, butyrate, $m$-hydroxybenzoate, malonate, oxalate, propionate, $\mathrm{D}$ - and L-tartarate. Cell wall peptidoglycan contains lysine as a diamino acid and the muramic acid of the cell wall is an acetyl type. The major isoprenoid quinone is menaquinone MK-10 and small amounts of MK-9 and MK-11 are present. The major fatty acids are anteiso- $\mathrm{C}_{15: 0}$ and anteiso $\mathrm{C}_{17: 0}$. The $\mathrm{G}+\mathrm{C}$ content is $65 \cdot 2 \mathrm{~mol} \%$. Isolated from cultivated mushroom Pleurotus ostreatus. Type strain is $\mathrm{CM}-01^{\mathrm{T}} \quad\left(=\mathrm{IFO} \quad 16274^{\mathrm{T}}=\mathrm{MAFF} \quad 211324^{\mathrm{T}}=\right.$ NRRL B-24119 ${ }^{\mathrm{T}}$ ).

\section{Description of Mycetocola tolaasinivorans sp. nov.}

Mycetocola tolaasinivorans (to.laa.si.ni.vo'rans. N.L. neut. n. tolaasinum tolaasin, type of toxin produced by Pseudomonas tolaasii; L. part. adj. vorans devouring, decomposing; N.L. part. adj. tolaasinivorans tolaasindecomposing).

Cells are Gram-positive, obligately aerobic, irregular rods, $0 \cdot 2-0 \cdot 4 \times 2 \cdot 0-3.5 \mu \mathrm{m}$, non-sporulating and nonmotile. Smooth, yellowish-white colonies are found on PS agar. The maximum temperature for growth is $33{ }^{\circ} \mathrm{C}$ and the optimal temperature for growth is $25^{\circ} \mathrm{C}$, but no growth at $4^{\circ} \mathrm{C}$ in PS broth medium. Catalase is produced, but oxidase is not produced. The following tests are positive: aesculin hydrolysis, growth in peptone water, acid production from D-cellobiose, dextrin, D-fructose, D-galactose, D-glucose, glycerol, lactose, maltose, D-mannitol, D-mannose, melibiose, D-ribose, salicin, D-sorbitol, sucrose, trehalose and D-xylose, utilization of fumarate, and detoxification of tolaasins produced by Pseudomonas tolaasii. The following tests are negative: reduction of nitrate or nitrite, nitrate respiration, liquefaction of gelatin, Voges-Proskauer reaction, methyl red reaction, lecithinase, tyrosinase, urease, hydrolysis of arbutin, arginine, casein and Tween 80 , production of diffusible and fluorescent pigment, hydrogen sulfide, indole, 3ketolactose, 2-ketogluconate and levan from sucrose, growth in Corn's solution, Fermi's solution and Uschinsky's solution, utilization of asparagine as sole source of carbon and nitrogen, maceration of potato tubers, hypersensitive reaction in tobacco leaves, acid production from D-arabinose, L-arabinose, D-dulcitol, erythritol, $m$-inositol, inulin, melezitose, D-raffinose, Lrhamnose and starch, and utilization of benzoate, butyrate, citrate, $m$-hydroxybenzoate, malonate, oxalate, propionate, D- and L-tartarate. Cell wall peptidoglycan contains lysine as a diamino acid and the muramic acid of the cell wall is an acetyl type. The major isoprenoid quinone is menaquinone MK-10 and small amounts of MK-9 and MK-11 are present. The $\mathrm{G}+\mathrm{C}$ content is $65.1 \mathrm{~mol} \%$. The major fatty acids are anteiso- $\mathrm{C}_{15: 0}$ and anteiso- $\mathrm{C}_{17: 0}$. Isolated from cultivated mushroom Pleurotus ostreatus. Type strain is CM- $05^{\mathrm{T}}\left(=\mathrm{IFO} 16277^{\mathrm{T}}=\mathrm{MAFF} 211325^{\mathrm{T}}=\mathrm{NRRL}\right.$ B-24120 $0^{\mathrm{T}}=$ strain $9405^{\mathrm{T}}$, described in Tsukamoto et al., 1998).

\section{Description of Mycetocola lacteus sp. nov.}

Mycetocola lacteus (lac.te'us. L. adj. lacteus milky).

Cells are Gram-positive, obligately aerobic, irregular rods, $0 \cdot 2-0 \cdot 4 \times 2 \cdot 0-3 \cdot 5 \mu \mathrm{m}$, non-sporulating and nonmotile. Smooth, yellowish-white colonies are found on PS agar. The maximum temperature for growth is $33{ }^{\circ} \mathrm{C}$ and the optimal temperature for growth is $25^{\circ} \mathrm{C}$, but no growth at $4{ }^{\circ} \mathrm{C}$ in PS broth medium. Catalase is produced, but oxidase is not produced. The following tests are positive: hydrolysis of aesculin and Tween 80 , growth in peptone water, acid production from D- 
cellobiose, dextrin, erythritol, D-fructose, D-galactose, D-glucose, glycerol, lactose, maltose, D-mannitol, Dmannose, melezitose, melibiose, D-ribose, salicin, Dsorbitol, sucrose, trehalose and D-xylose, utilization of citrate and fumarate, and detoxification of tolaasins produced by Pseudomonas tolaasii. The following tests are negative: reduction of nitrate or nitrite, nitrate respiration, liquefaction of gelatin, Voges-Proskauer reaction, methyl red reaction, lecithinase, tyrosinase, urease, hydrolysis of arbutin, arginine and casein, production of diffusible and fluorescent pigment, hydrogen sulfide, indole, 3-ketolactose, 2-ketogluconate and levan from sucrose, growth in Corn's solution, Fermi's solution and Uschinsky's solution, utilization of asparagine as sole source of carbon and nitrogen, maceration of potato tubers, hypersensitive reaction in tobacco leaves, acid production from Darabinose, L-arabinose, D-dulcitol, $m$-inositol, inulin, D-raffinose, L-rhamnose and starch, and utilization of benzoate, butyrate, $m$-hydroxybenzoate, malonate, oxalate, propionate, D- and L-tartarate. Cell wall peptidoglycan contains lysine as a diamino acid and the muramic acid of the cell wall is an acetyl type. The major isoprenoid quinone is menaquinone MK-10 and small amounts of MK-9 and MK-11 are present. The major fatty acids are anteiso- $\mathrm{C}_{15: 0}$ and anteiso- $\mathrm{C}_{17: 0}$. The $\mathrm{G}+\mathrm{C}$ content is $63.9-64.7 \mathrm{~mol} \%$. Isolated from cultivated mushroom Pleurotus ostreatus. Type strain is $\mathrm{CM}-10^{\mathrm{T}} \quad\left(=\mathrm{IFO} \quad 16278^{\mathrm{T}}=\mathrm{MAFF} \quad 211326^{\mathrm{T}}=\right.$ NRRL B-24121 ${ }^{\mathrm{T}}$ ).

\section{ACKNOWLEDGEMENTS}

We are grateful to Dr Koushi Nishiyama, National Institute of Agro-Environmental Sciences, for the direction of biochemical and physiological tests and to Dr Hiroaki Noda, National Institute of Sericultural and Entomological Sciences, for the direction of phylogenetic analysis of $16 \mathrm{~S}$ rRNA gene.

\section{REFERENCES}

Azegami, K., Nishiyama, K., Watanabe, Y., Kadota, I., Ohuchi, A. \& Fukazawa, C. (1987). Pseudomonas plantarii sp. nov., the causal agent of rice seedling blight. Int J Syst Bacteriol 37, 144-152.

Davis, M. J., Gillaspie, A. G., Jr, Vidaver, A. K. \& Harris, R. W. (1984). Clavibacter: a new genus containing some phytopathogenic coryneform bacteria, including Clavibacter xyli subsp. xyli sp. nov., subsp. nov., and Clavibacter xyli subsp. cynodontis subsp. nov., pathogens that cause ratoon stunting disease. Int J Syst Bacteriol 34, 107-117.

Dye, D. W. (1962). The inadequacy of the usual determinative tests for the identification of Xanthomonas spp. $N Z J$ Sci 5 , 393-416.

Dye, D. W. (1968). A taxonomic study of the genus Erwinia. I. The 'amylovora' group. N Z J Sci 11, 590-607.

Evtushenko, L. I., Dorofeeva, L. V., Subbotin, S. A., Cole, J. R. \& Tiedje, J. M. (2000). Leifsonia poae gen. nov., sp. nov., isolated from nematode galls on Poa аппиа, and reclassification of 'Corynebacterium aquaticum' Leifson 1962 as Leifsonia aquatica (ex Leifson 1962) gen. nov., nom. rev., comb. nov. and
Clavibacter xyli Davis et al. 1984 with two subspecies as Leifsonia xyli (Davis et al. 1984) gen. nov., comb. nov. Int J Syst Evol Microbiol 50, 371-380.

Ezaki, T., Hashimoto, Y. \& Yabuuchi, E. (1989). Fluorometric deoxyribonucleic acid-deoxyribonucleic acid hybridization in microdilution wells as an alternative to membrane filter hybridization in which radioisotopes are used to determine genetic relatedness among bacterial strains. Int J Syst Bacteriol 39, 224-229.

Felsenstein, J. (1985). Confidence limits on phylogenies: an approach using the bootstrap. Evolution 39, 783-791.

Gledhill, W. E. \& Casida, L. E. Jr (1979). Predominant catalasenegative soil bacteria III. Agromyces, gen. nov., microorganisms intermediary to Actinomyces and Nocardia. Appl Microbiol 18, 340-349.

Groth, I., Schumann, P., Weiss, N., Martin, K. \& Rainey, F. A. (1996). Agrococcus jenensis gen. nov., sp. nov., a new genus of actinomycetes with diaminobutyric acid in the cell wall. Int $J$ Syst Bacteriol 46, 234-239.

Harper, J. J. \& Davis, G. H. G. (1979). Two-dimensional thin-layer chromatography for amino acid analysis of bacterial cell walls. Int J Syst Bacteriol 29, 56-58.

Kämpfer, P., Rainey, F. A., Andersson, M. A., Nurmiaho Lassila, E.-L., Ulrych, U., Busse, H.-J., Weiss, N., Mikkola, R. \& SalkinojaSalonen, M. (2000). Frigoribacterium faeni gen. nov., sp. nov., a novel psychrophilic genus of the family Microbacteriaceae. Int J Syst Evol Microbiol 50, 355-363.

Kimura, M. (1980). A simple method for estimating evolutionary rates of base substitutions through comparative studies of nucleotide sequences. J Mol Evol 16, 111-120.

Minnikin, D. E., Collins, M. D. \& Goodfellow, M. (1979). Fatty acid and polar lipid composition in the classification of Cellulomonas, Oerskovia and related taxa. J Appl Bacteriol 47, 87-95.

Nishiyama, K. (1981). Studies on the pathogenicity-related substances in Pseudomonas coronafaciens var. atropurpurea. Bull Natl Inst Agric Sci 35, 1-55.

Nutkins, J. C., Mortishire-Smith, R. J., Packman, L. C., Brodey, C. L. P. B., Johnstone, K. \& Williams, D. H. (1991). Structure determination of tolaasins, an extracellular lipodepsipeptide produced by the mushroom pathogen Pseudomonas tolaasii Pine. J Am Chem Soc 113, 2621-2627.

Saitou, N. \& Nei, M. (1987). The neighbor-joining method: a new method for reconstructing phylogenetic trees. Mol Biol Evol 4, 406-425.

Schleifer, K. H. \& Kandler, O. (1972). Peptidoglycan types of bacterial cell walls and their taxonomic implications. Bacteriol Rev 36, 407-477.

Shirata, A., Sugaya, K., Takasugi, M. \& Monde, K. (1995). Isolation and biological activity of toxins produced by a Japanese strain of Pseudomonas tolaasii, the pathogen of bacterial rot of cultivated Oyster mushroom. Ann Phytopathol Soc Jpn 61, 493-502.

Stackebrandt, E., Rainey, F. \& Ward-Rainey, N. L. (1997). Proposal for a new hierarchic classification system, Actinobacteria classis nov. Int J Syst Bacteriol 47, 479-491.

Suyama, K. \& Fujii, H. (1993). Bacterial disease occurred on cultivated mushroom in Japan. J Agric Sci Tokyo Nogyo Daigaku 38, 35-50.

Suzuki, K., Sasaki, J., Uramoto, M., Nakase, T. \& Komagata, K. (1997). Cryobacterium psychrophilum gen. nov., sp. nov., nom. rev., comb. nov., an obligately psychrophilic actinomycete to 
accommodate 'Curtobacterium psychrophilum' Inoue and Komagata 1976. Int J Syst Bacteriol 47, 474-478.

Takagi, H., Shida, O., Kadowaki, K., Komagata, K. \& Udaka, S. (1993). Characterization of Bacillus brevis with descriptions of Bacillus migulanus sp. nov., Bacillus choshinensis sp. nov., Bacillus parabrevis sp. nov., and Bacillus galactophilus sp. nov. Int J Syst Bacteriol 43, 221-231.

Takeuchi, M. \& Hatano, K. (1998). Union of the genera Microbacterium Orla-Jensen and Aureobacterium Collins et al. in a redefined genus Microbacterium. Int J Syst Bacteriol 48, 739-747.

Takeuchi, M., Weiss, N., Schumann, P. \& Yokota, A. (1996). Leucobacter komagatae gen. nov., sp. nov., a new aerobic Gram-positive, nonsporulating rod with 2,4-diaminobutyric acid in the cell wall. Int J Syst Bacteriol 46, 967-971.

Thompson, J. D., Higgins, D. G. \& Gibson, T. J. (1994). CLUSTAL $\mathrm{W}$ : improving the sensitivity of progressive multiple sequence alignment through sequence weighting, position specific gap penalties and weight matrix choice. Nucleic Acids Res 22, 4673-4680.

Tolaas, A. G. (1915). A bacterial disease of cultivated mushrooms. Phytopathology 5, 51-54.
Tsukamoto, T., Shirata, A. \& Murata, H. (1998). Isolation of a Gram-positive bacterium effective in suppression of brown blotch disease of cultivated mushrooms, Pleurotus ostreatus and Agaricus bisporus, caused by Pseudomonas tolaasii. Mycoscience 39, 273-278.

Uchida, K., Kudo, T., Suzuki, K. \& Nakase, T. (1999). A new rapid method of glycolate test by diethyl ether extraction, which is applicable to a small amount of bacterial cells of less than one milligram. J Gen Appl Microbiol 45, 49-56.

Wakimoto, S. (1955). Studies on the multiplication of OP1 phage (Xanthomonas oryzae bacteriophage) 1. One-step growth with experiment under various conditions. Sci Bull Fac Agric Kyushu Univ 15, 151-160.

Yamada, K. \& Komagata, K. (1972). Taxonomic studies on coryneform bacteria. IV. Morphological, cultural, biochemical and physiological characteristics. J Gen Appl Microbiol 18, 399-416.

Zgurskaya, H. L., Evtushenko, L. I., Akimov, V. N. \& Kalakoutskii, L. V. (1993). Rathayibacter gen. nov., including the species Rathayibacter rathayi comb. nov., Rathayibacter tritici comb. nov., Rathayibacter iranicus comb. nov., and six strains from annual grass. Int J Syst Bacteriol 43, 141-149. 